\title{
HOW PROSODY CONSTITUTES THE ACTIONS OF FORMULATIONS IN COURTROOMS ${ }^{1}$
}

\section{COMO A PROSÓDIA CONSTITUI AÇÕES DE FORMULAÇÕES NA CORTE}

\author{
Ana Cristina Ostermann | Lattes |ACO@unisinos.br \\ Universidade do Vale do Rio dos Sinos
}
Daniela Negraes Pinheiro Andrade | Lattes | danielanegraes23@gmail.com
Universidade do Vale do Rio dos Sinos

\begin{abstract}
Minéia Frezza | Lattes | mineiafrezza@hotmail.com
Universidade do Vale do Rio dos Sinos
\end{abstract}

\begin{abstract}
Resumo: Com base nas perspectivas teóricas e metodológicas da Linguística Interacional e da Análise da Conversa, este estudo investiga como o traço prosódico tom contribui para a formação e a atribuição de sentido às ações em audiências de instrução, em particular, na prática de formulação. A análise revela que variações de tom na prática de perguntar estão intrinsecamente relacionadas às diferentes ações realizadas local e situadamente: checar entendimento e desafiar o interlocutor.
\end{abstract}

Palavras-chave: Análise da conversa; Linguística interacional; Prosódia; Formulações.

Abstract: Based on the theoretical and methodological perspectives of Conversation Analysis and Interactional Linguistics, this study investigates how the prosodic feature pitch contributes to the formation and ascription of actions in court hearings, in particular, in practices of formulation. The analysis reveals that variations of pitch in the practice of formulating are intrinsically related to the different locally and situated actions performed: checking understandings and challenging the interlocutor.

Key words: Conversation Analysis; Interactional Linguistics; Prosody; Formulations.

\footnotetext{
${ }^{1}$ A modified and extended version of the discussion presented here was published in Brazilian Portuguese in http://ken.pucsp.br/delta/article/viewFile/20030/22218.
} 


\section{Introduction}

Based on the perspectives of Conversation Analysis and Interactional Linguistics, this paper analyzes the prosodic features of courtroom interactions that present the interactional practice of formulating conversation. Formulations are described as an interactional practice that allows participants to perform different actions insofar as they enable "[... ] co-participants to settle on one of many possibilities of what they have been saying" (HERITAGE; WATSON, 1979, p. 123). In this sense, a formulation "constitutes a shift from the exchange of information and particulars about the issues under negotiation to a review of 'where we/you are"' (WALKER, 1995, p. 104) which orients the interlocutor to the implementation of certain subsequent actions (HERITAGE; WATSON, 1979). Such orientation may be observed and described insofar as the production of a formulation opens the first-pair part of an adjacent pair (e.g. checking understanding) and makes the interlocutor responsible for providing the second-pair part of the adjacency pair (e.g. confirming/disconfirming that understanding) to close that conversation sequence.

Occurrences of formulation are not abundantly observed in ordinary talk but are more likely to happen in institutional talk - e.g. court hearings, police interrogations, decision-making meetings - due to "institutionalized distribution of rights to formulate" (HERITAGE; WATSON, 1979, 150). In this paper, we will specifically discuss two types of actions performed through the practice of formulating: (a) checking understanding and (b) challenging the interlocutor. The second action (b) may be observed when the formulation done as the first-pair part requires that the interlocutor provides an account as the second-pair part of the adjacency pair (SACKS, 1992). While type (a), checking understanding, is one of the most recurrent actions implemented with the use of formulations, even in ordinary talk, challenging the interlocutor seems to be much less common. However, as providing accounts is one of the main characteristics of interactions in hearing audiences, it might not be surprising to find a collection of them in such context which, per se, justifies this study. In addition, the investigation of the role prosodic features play in the practice of formulating should contribute for enlarging the studies of naturally occurring interactions in Brazilian Portuguese, in particular from the interactional linguistic and conversation analytic perspectives.

\section{Prosody in naturally occurring interactions}

When Sacks, Schegloff and Jefferson (1974) proposed Conversation Analysis (CA) methodology to describe social order based on the empirical investigation of 
naturally occurring interactions, they called attention to the importance of phenomena such as hesitation, pauses, laughter, sound lengthening, inspiration, expiration, speech cut-offs, pitch, and intonation, to the local and situated co-construction of interactional actions. Since the very beginning of CA studies, then, prosody has been understood as one of the resources participants rely on to manage, negotiate, and attribute meaning to social actions in interaction (COUPER-KUHLEN; SELTING, 1996; LEVINSON, 2013).

In order to assist CA researchers to understand in which ways prosody operates in action formation and ascription in naturally occurring interactions, Emanuel Schegloff (1998) suggests two analytical approaches: (a) focusing the research on comparative analysis of prosodic phenomena on occasions of spontaneous talk-in-interaction events and other contexts (e.g. reading); (b) focusing the research on conversational events in order to investigate prosody as one of the elements which contribute to its organization. Our research follows the second analytical approach (b). Hence, we take prosody as a set of resources which contribute to the production of talk-in-interaction, focusing on how it contributes to meaning ascription of certain actions (i.e. checking understanding and challenging the interlocutor) in formulations produced in the courtroom interactions.

\section{Methodology}

This study follows a qualitative analytical approach, with the data analysis discussion being supported by a combination of the theoretical and methodological perspectives of Conversation Analysis (CA) and Interactional Linguistics (IL). As CA was first developed in a sociological intellectual environment, several studies in the area have recurrently neglected some linguistic aspects of talk such as prosody. According to Selting (2010, p. 6), "there is no spoken language without prosody, and disregarding prosody in the study of spoken language means disregarding an integral part of spoken language itself." By aiming at fulfilling this gap - on what concerns interactional linguistic studies of Brazilian Portuguese - we rely on the theoretical and methodological approach of Interactional Linguistics which investigates how prosody - as a suprasegmental aspect - may contribute to the ascription of meaning to specific interactional actions in naturally occurring conversation.

Following Conversation Analysis premises to generate data, the methodological procedures undertaken were: (a) observing and audio recording 59 hearing audiences; (b) transcribing all recordings; (c) continuously listening to the recordings together 
with finely revising the transcripts; (d) building a collection of recurring patterns of formulations done by the institutional representative; (e) sequentially analyzing the actions implemented by means of formulations; (f) by using the software Praat, analyzing the prosodic features of the turns of talk in which formulations were produced; and $(\mathrm{g})$ investigating the role of prosody in the accomplishment of the specific actions in formulations.

Part of CA and IL research comprises transcribing data based on a set of conventions that intend to allow readers to understand what was said beyond the reproduction of standard orthography. The convention system chosen to transcribe data was the Jeffersonian one, which represents "a magical engagement with the lived moment-by moment features of interaction" (HEPBURN; BOLDEN, 2017), as represented in Figure 1.

Figure 1. Jeffersonian conventions

Transcription conventions based on Jefferson (1984)

\begin{tabular}{|c|c|}
\hline$(1.8)$ & Sound \\
\hline (.) & Micro pause \\
\hline$=$ & Latched talk \\
\hline [text] & Overlap \\
\hline 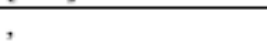 & Continuing intonation \\
\hline$\uparrow$ text & $\begin{array}{l}\text { Rising intonation immediately following the } \\
\text { arrow }\end{array}$ \\
\hline$\downarrow$ text & $\begin{array}{l}\text { Falling intonation immediately following the } \\
\text { arrow }\end{array}$ \\
\hline . & The whole turn is produced in falling intonation \\
\hline$?$ & The whole turn is produced in rising intonation \\
\hline- & Abrupt cutoff \\
\hline$:::$ & Sound lengthening \\
\hline$>\operatorname{text}<$ & Quicker pace than the surrounding talk \\
\hline$<$ text $>$ & Slower pace than the surrounding talk \\
\hline TEXT & Louder than the surrounding talk \\
\hline${ }^{\circ} \operatorname{text}^{\circ}$ & Quieter than the surrounding talk \\
\hline text & Emphasis \\
\hline (text) & Transcriptionist doubt \\
\hline $\mathrm{xxxx}$ & Inaudible talk \\
\hline ((Texto. $))$ & $\begin{array}{l}\text { Vocalizations and other details of the } \\
\text { conversational scene }\end{array}$ \\
\hline hhhh hahahehehihi & Laughter \\
\hline .hhh & Audible inhale \\
\hline hhh & Audible exhale \\
\hline
\end{tabular}

Source: Jefferson (1984, p. ix-xvi).

As for analyzing prosody, to build collections, we focused on the instances in which the prosodic patterns revealed in the formulations produced different actions. The selected extracts focus on one of the institutional representative's talk: a female judge. 
Such decision was grounded on Szczepek Reed's (2010) orientations for conducting prosodic analyses: firstly, by comparing extracts of talk produced by the same person and, secondly, by comparing extracts of talk produced by different people engaged in a conversation. From our corpus of 59 interactions, we selected two instances in which the practice of formulations was constituted as a means of checking understanding, and two formulations used to challenge the interlocutor. For this the purposes of this paper, we discuss how these two types of formulation differ in terms of prosody by showing one occurrence from each collection.

The excerpts cited in this article are transcribed in three lines: for each numbered line, there is the transcription in Brazilian Portuguese, the original language of the data. The second line presents a word-by-word English gloss, and the third one, a free English translation.

\section{Data analysis}

Excerpt 1 shows how the action of checking understanding via formulation also accomplishes the action of putting information "on record" - one of the legal settings' institutional goals (ANDRADE, 2010). The excerpt under scrutiny is part of a hearing audience in which the judge (JUD) interrogates the defendant (DEF) about his involvement with the crime of drug dealing (crack). In the previous turns of talk (not shown here), the defendant claims he is not involved with the alleged crime and points out his son as the plaintiff. The defendant also claims his son was a drug addict at the time the crime was perpetrated.

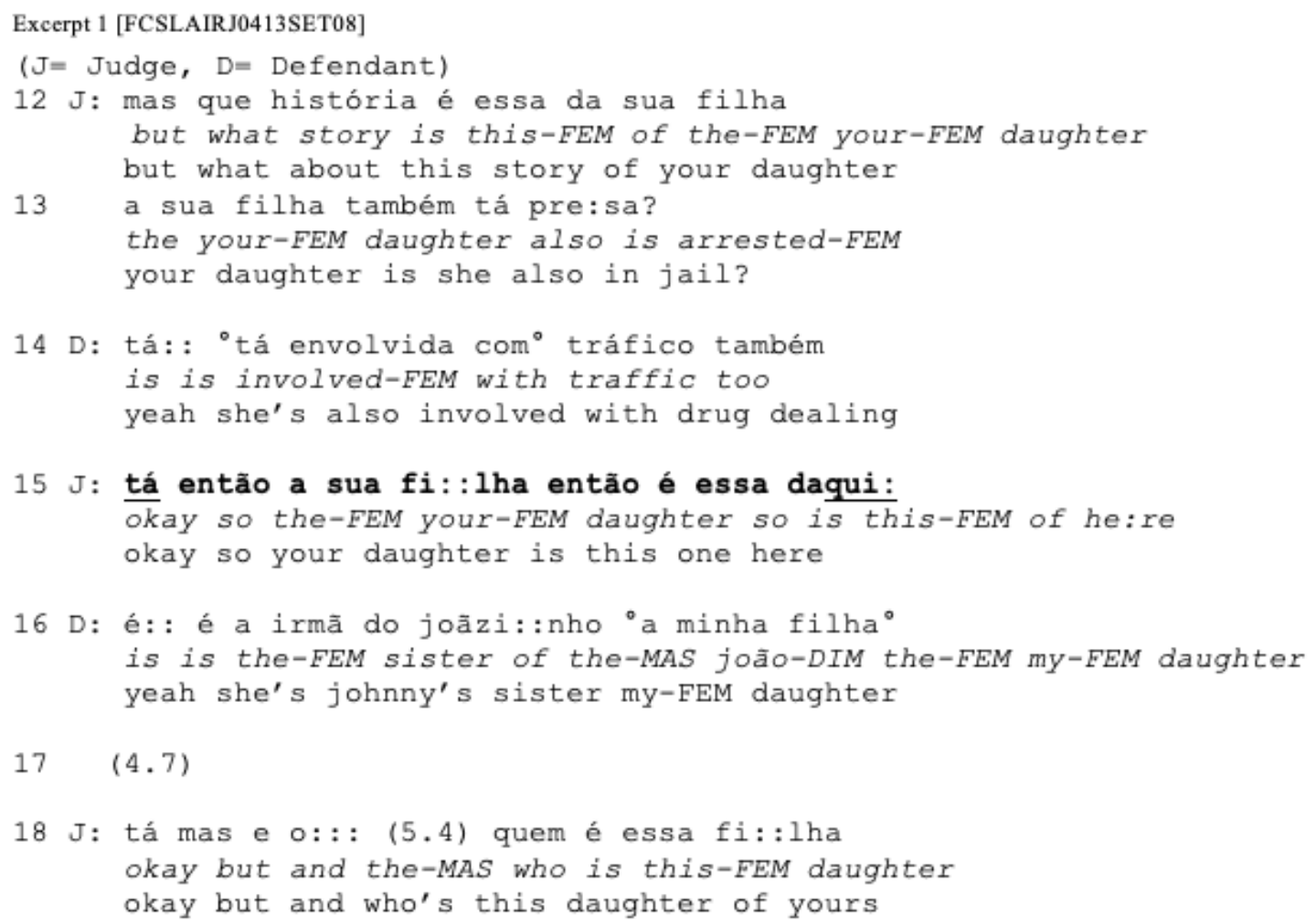


Based on the defendant's testimony and on the dossier the judge holds in her hands, ${ }^{2}$ the judge orients to the defendant's daughter's involvement in the legal process being analyzed: "but what about this story of your daughter is she also in jail?" (line 1213). The defendant responds confirming that information.

In addition, the defendant offers more information than what he had been requested. He provides the judge the reason why his daughter is in jail, that is, she is involved with drug dealing. The judge, then, formulates her understanding concerning the defendant's daughter's identity: "okay so your daughter is this one here" (line 15). ${ }^{3}$ The defendant does not treat the judge's turn as an assertion, but as request for confirmation of an understanding instead, as he provides the second-pair part of the adjacency-pair initiated by judge when she formulates her understanding concerning the daughter's identity. In so doing, he confirms his daughter's identity (line 16). The action of checking understanding performed via formulation may be observed (a) in the sequence in which the formulation is in the conversation (line 15), given the interlocutor's adjacent confirmation (line 16).

To analyze the pitch range when such formulation is produced, it is important to inform that the judge's pitch range oscillates between $140 \mathrm{~Hz}$ and $360 \mathrm{~Hz}$ and her average range is approximately $270 \mathrm{~Hz}$. The fundamental frequency contour of the turn of talk where she produces a formulation shows that when she produces "okay" ( $t a ́)$, in the beginning of the turn, the pitch range reaches $288 \mathrm{~Hz}$. Later, when she produces "so" (então) - a discourse marker commonly used to express logical deduction such as "if p, so q", and commonly used in formulations -, the pitch range falls to $228 \mathrm{~Hz}$. Then, the pitch range increasingly rises and reaches its peak when the judge produces the deictic "here" (daqui) $(347 \mathrm{~Hz})$. In addition, we can notice that word lengthening presents rising pitch range as well.

\footnotetext{
${ }^{2}$ Information based on field notes.

${ }^{3}$ Field notes show that in line 15, when the judge produces "this one", she is pointing to the dossier she is handling.
} 
Figure 2. Fundamental frequency contour of "so your daughter is this one here"

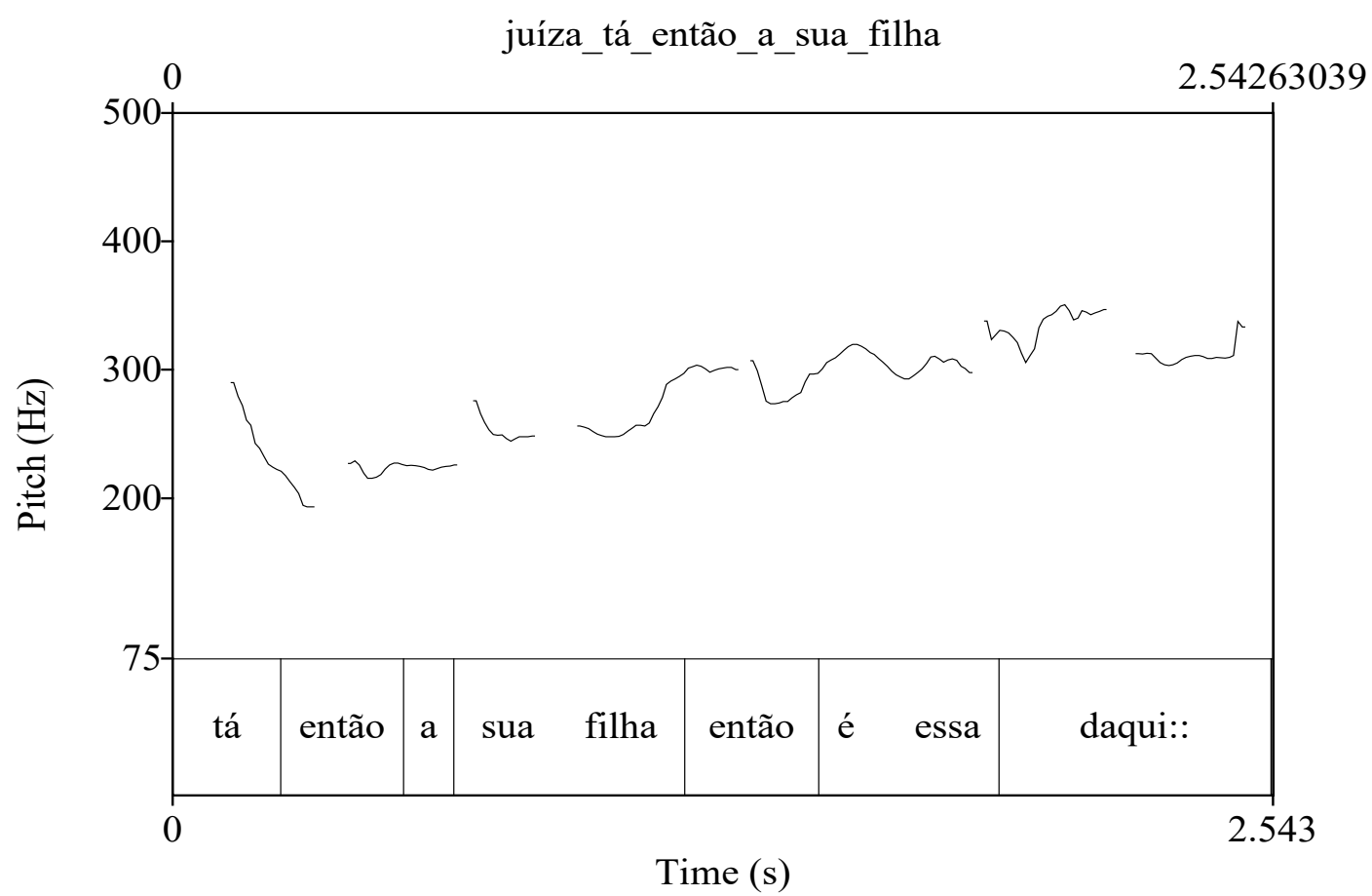

The fundamental frequency contour shows that the pitch of the formulation: (a) presents a continuously rising curve after the "so" (então); and (b) reaches its peak when the judges expresses her understanding about who the deponent's daughter is - that is, "this one here" (essa daqui:) and nobody else who had been mentioned up to that moment. This analysis shows that the prosodic features produced by the judge during a formulation that checks understanding are different from the ones that challenge the interlocutor, as discussed later in this paper. The challenging character of certain turns is not given aprioristically but evidenced by the orientation of the next speaker; i.e. based on the next speaker's contribution to the ongoing interaction. One of the most concrete emic evidence which can work as proof procedure that the next speaker has understood certain turn as a "challenge" is their provision of accounts in their next turn. We show next how this happens.

In Excerpt 2, the legal case refers to a woman who claims to restore the custody of her child that, after her parents' divorce, got under the father's responsibility, who is the deponent's former husband. The deponent (DEP), who is the child's mother, alleges to have been forced to get divorced because of domestic violence due to groundless suspicion that she had betrayed her husband. The following interaction happens after the judge (JUD) inquires the deponent about her current partner. 


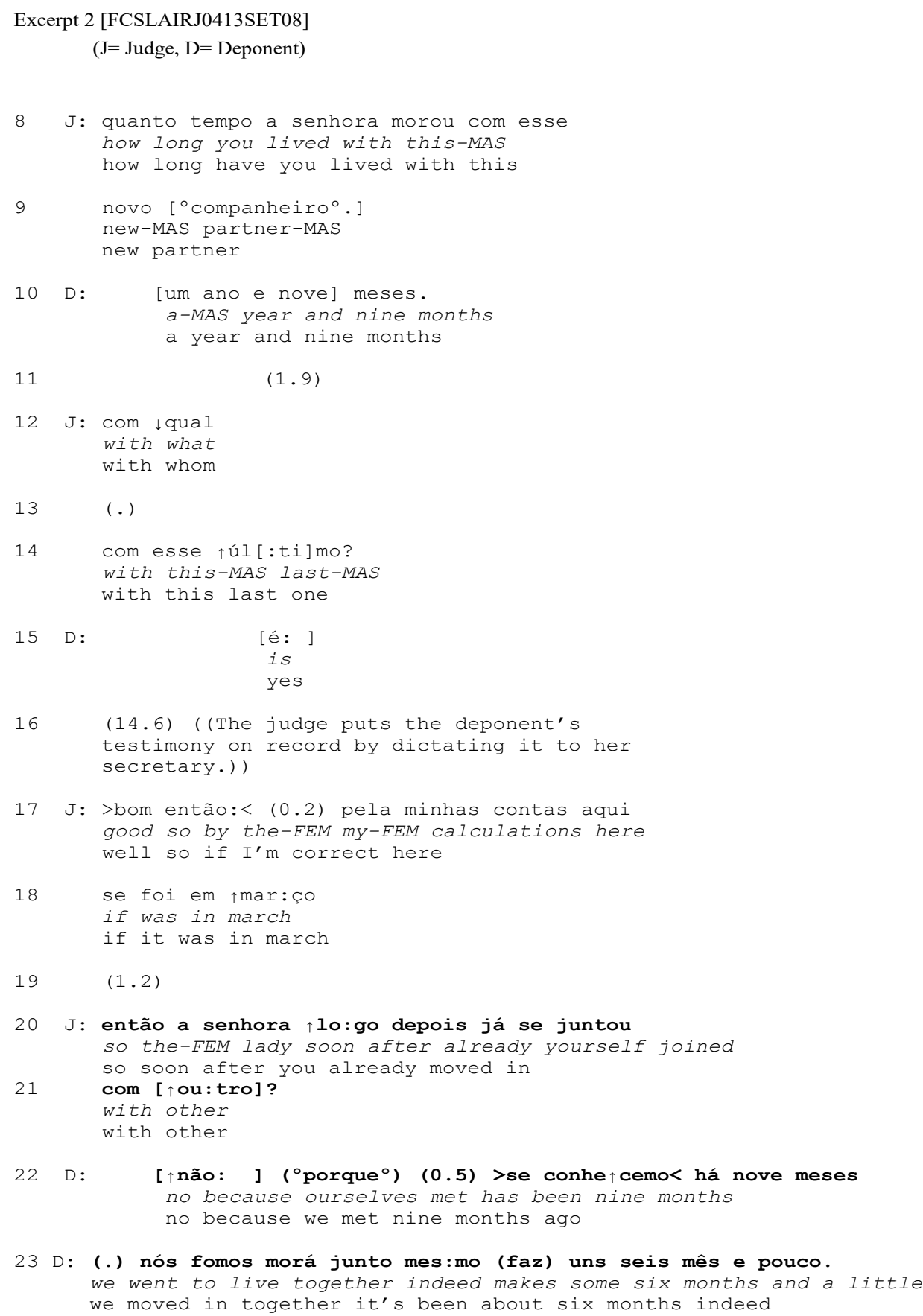

The judge requests the time length the deponent has lived with her new partner, which is responded to in line 10. The judge then produces a formulation (line 17-20), which is actually "held up" during its production (see gap in line 19). The design of such turn of talk (lines 17-20) is particularly interesting because it shows the reflexive procedure (GARFINKEL, 1967) that grounds the judge's conclusion socially shared by means of a formulation in line 20. In fact, the judge shows that her "math reasoning" 
had already started in line 17. This explains the absence of talk in line 19 - somewhat longer than others in this interaction - but which is possibly a result of time the judge needs to calculate the amount of time it took the deponent to move in with another man after the break up so - presented by means of a formulation. Sacks (1992) illuminates the analysis of the second part of the formulation of the judge.

In addition to the demand that conversation analysts build their analysis based on the sequential organization formed by the turns of talk, Schegloff (2007) claims that it is necessary to consider the various layers that operate on talk organization. He claims that the organizational layers work on the sequentiality of the adjacency pairs, on the macrostructure of conversation and on the topics made relevant in the conversation. In terms of this last aspect, Sacks (1992) says that whenever it is not possible to end up a topic in one adjacency pair, the topic tends to be expanded so as to connect what we had been saying previously to what we are saying now, even if we are not talking about the same thing now. The formulation in Excerpt 2 seems to request an elaboration from the deponent about her relationship with her current interactional partner. Thus, the formulation of the judge requests an account and challenges the deponent about the truth of facts that her former husband's suspiciousness was groundless.

As our analytic object consists of an adjacency pair, it is crucial to check its second pair-part - the deponent's answer (lines 22-23) - that is produced in overlap with the end of the judge's formulation. The deponent shows her orientation to provide an account as she explains that she had first met her current partner and only after a certain amount of time had moved in with him. The account provided by the deponent can be interpreted as evidence that the deponent had oriented herself to the judge's talk as a potential "moral" challenge of her being a "decent woman" and of her version of the facts.

In terms of prosody, Figure 3 represents that the production of this formulation differs from the one analyzed in Excerpt 1. 
Figure 3. Fundamental frequency contour of "so you soon after moved in with another". então_a_senhora_logo_depois_já_se_juntou_com_outro

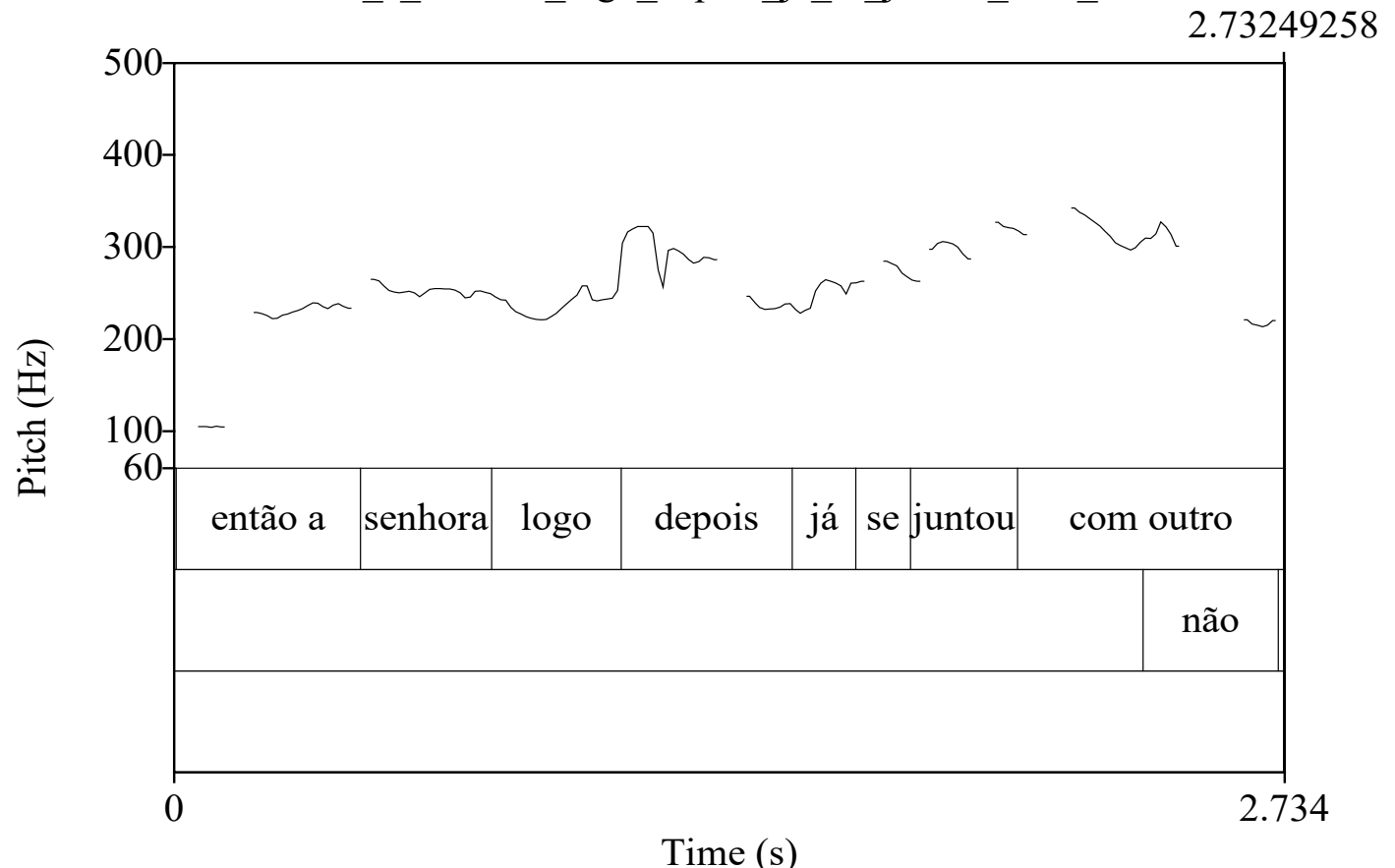

The connector "so" (então) is produced with rising pitch range (starting at $105 \mathrm{~Hz}$ and ending at $234 \mathrm{~Hz}$ ). Then, the pitch remains high along part of the production of the pronoun "you" (senhora). The adverb "soon" $(\log o)$ reaches a much higher pitch range (starting at $242 \mathrm{~Hz}$ and ending at $322 \mathrm{~Hz}$ ), especially when compared to the last syllable of the previous word. Soon after the pitch range falls again and reaches a new peak at the moment the judge produces the word "another" (outro) (starting at $342 \mathrm{~Hz}$ and ending at $223 \mathrm{~Hz}$ ). Therefore, the words "soon" and "another" are both produced with higher pitch, which, seen from a semantic perspective, locally and sequentially speaking, constitute the focus of the challenge done via this formulation. In addition to these lexical choices, the prosody the judge uses to produce these words contributes to the construction of the turn as potentially implementing the action of challenging. To justify our analysis, we rely on Couper-Kuhlen and Selting's claim (1996, p. 21) concerning the "pragmatic meaning" a certain intonation can bear in situated contexts, by claiming that the prosody used in the turn where the formulation is produced by the judge (in Excerpt 2) makes a negative type-conforming response (RAYMOND, 2003) preferred. Our analytical argument, thus, underpins the statement of Couper-Kuhlen and Selting (1996, p. 21), in which they affirm that "prosodic contextualization cues are not referential, but indexical, signs" and, therefore, are imperative to the analytic studies which are embedded with the 
description of the social machinery of language. The formulation contained in Excerpt 2 has a prosodic production that can operate to: (a) transform the polarity of the preferred response (i.e., confirmation or disconfirmation), and (b) make an account relevant in the next turn. To sum up, the pragmatic meaning imprinted by the judge's prosody onto her turn of talk where the formulation is produced works to challenge the deponent. The deponent's account (line 25-26) becomes the next turn proof procedure that the deponent does indeed ascribe the action of a request for an account to the judge's formulation.

\section{Conclusions}

This study reveals how the actions of information checking and of challenging are implemented also using different prosodic features. Based on Levinson's (2013) proposal, we analyzed prosody as part of a linguistic and formal layer combined to a sequential and contextual analysis to describe how the process of designing and ascribing meaning to the actions implemented by the practice of formulating takes place.

Importantly, the lexical choices that represent the focus of judge's formulations (either as checking understanding or challenging the information provided) are produced prominently. As a result, the next speaker is led to interpret the formulations based on the pragmatic meaning indicated by their marked prosody.

Therefore, we claim that the prosodic characteristics observed in the judge's formulations work as another layer in the design and meaning ascription of the actions being implemented (LEVINSON, 2013): formulating to check understanding and formulating to request for accounts (the latter working some type of confrontation). Two factors support such claim: (a) the clue that the actions are based on the emphasis of the terms to be confirmed or disconfirmed by the next speakers, and, (b) by the next speakers' orientations to provide the second pair-part displaying how they ascribe meaning to the expectations generated by prosody used in the actions implemented in the first pair-part.

\section{References}

ANDRADE, D. O uso de referentes pessoal e de lugar e o uso de formulações em interrogatórios na corte, São Leopoldo. Master's Dissertation. Universidade do Vale do Rio dos Sinos UNISINOS, 2010.

COUPER-KUHLEN, E.; SELTING M. (Ed.). Prosody in conversation: interactional studies. New York: Cambridge University Press, 1996.

GARFINKEL, H. Studies in Ethnomethodology. Englewood Cliffs, 1967.

HEPBURN, A.; BOLDEN, G. Transcribing for social research. Los Angeles: Sage Publications, 2017. 
HERITAGE, J.; WATSON, R. Formulations as conversational objects. In: PSATHAS, G. (Ed.), Everyday language: studies in ethnomethodology. Mahwah: Lawrence Erlbaum Associates, 1979, p. 123-162.

JEFFERSON, G. Transcript notation. In: ATKINSON, J.; HERITAGE, J. Structures of social action: studies in conversation analysis. New York: Cambridge University Press, 1984. p. ix-xvi.

LEVINSON, S. Action formation and ascription. In: SIDNELL, J.; STIVERS, T. (Ed.). The Handbook of Conversation Analysis. Massachusetts: Wiley-Blackwell, 2013, p. 103130.

RAYMOND, G. Grammar and social organization: yes/no interrogatives and the structure of responding. American Sociological Review, v. 68, p. 939-967, 2003.

SACKS, H. Lectures on conversation. Oxford: Blackwell, v. 1 e v. 2, 1992.

; SCHEGLOFF, E.; JEFFERSON, G. The simplest systematics for turn-taking in conversation”. Language, v. 50, n. 4, p. 696-735, 1974.

SCHEGLOFF, E. Reflections on studying prosody in talk-in-interaction, Language and Speech, v. 42, n. 3-4, p. 235-263, 1998.

- Sequence organization in interaction: a primer in Conversation Analysis. Cambridge: Cambridge University Press, v. 1, 2007.

SELTING, M. Prosody in interaction: State of the art. In: BARTH-WEINGARTEN, D.; REBER, E.; SELTING, M. (Ed.). Prosody in interaction. Amsterdam: Benjamins, 2010, p. $3-40$.

SZCZEPEK REED, B. Analysing conversation: an introduction to prosody. New York: Palgrave Macmillan, 2010.

WALKER, E. Making a bid for change: formulations in union/management negotiations. In: FIRTH, A. (Ed.). The discourse of negotiation: studies of language in the workplace. Oxford: Pergamon, 1995, p. 101-140.

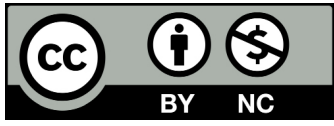

Data de submissão: 18/01/2018

Data de aceite: $18 / 09 / 2018$ 